\title{
Subjectivation, Democracy and Cosmopolitics
}

\author{
Rosa Nidia Buenfil Burgos ${ }^{1, *}$ \\ ${ }^{1}$ Department of Educational Research, Center for Research and Advanced Studies, Mexico City, Mexico \\ *Correspondence: Department of Educational Research, Center for Research and Advanced Studies, Mexico City, \\ Mexico_E-mail: rbuenfil@civestav.mx and buenfil_rn@yahoo.com
}

Received: November 22, 2012

Accepted: January 24, $2013 \quad$ Online Published: February 2, 2013

doi:10.5430/wje.v3n1p52

URL: http://dx.doi.org/10.5430/wje.v3n1p52

\begin{abstract}
The topic of subjectivity has been the object of permanent, intense and diverse inquiries from various areas of study. In this presentation I will question the crux of subjectivation within the framework of a democratic horizon and cosmopolitical discussion. The position of this paper is postfoundational; it revisits the critique of the subject as the source and origin of meaning; it adheres to the Wittgensteinian notion of meaning as the use of an expression within the play of language; it subscribes to the paradoxical interpretation of democracy (Mouffe) and a pluralistic cosmopolitical point of view in the face of a conciliatory cosmopolitanism.
\end{abstract}

Keywords: subjectivity; identification; cosmopolitanism and cosmopolitics; paradoxical democracy

The topic of subjectivity has been the object of permanent, intense and diverse inquiries. It is a point of conjunction not only for diverse disciplines, but also for various conceptual positionings. From Greek philosophy to postmodern thought - to mention only the West - the questioning of subjectivity has been a part of the intellectual efforts of outstanding thinkers. The desire to define once and for all the essence of the subject has been a goal of philosophers, political scientists, sociologists, educators, psychologists, anthropologists, etc. Reason, nature, economy, among others, have occupied the central position for explaining the origin, nucleus and ultimate end of identity, especially in the thought of the Enlightenment and its subsequent developments (e.g. rationalism in its various aspects). Nevertheless, after Nietzsche, Freud, Marx and Heidegger, doubts about its transcendental, universal and atemporal essence have grown. Today, there are diverse schools of thought that offer arguments for "losing innocence" in the face of desires for fulfillment related to habitual forms of essentialisms and fundamentalisms.

In this paper I will question the core of subjectivation within the framework of a democratic horizon and cosmopolitical discussion. The relationships between democracy and education can be constructed from multiple angles, some of which I will mention now only with the intention of contextualizing my own approach on this occasion. They can be confronted for prescriptive purposes, attempting to offer a set of values leading to a democratic life and making them operable in schooling practices across the board or localized in specific subjects (such as civics).(Note 1) We can describe the democratic characteristics practiced (or not practiced) in the classroom. We can develop a critical proposal regarding the absence of democratic values in the curricula of educational systems. Neither of these possibilities concerns me.

My intention has as its starting point the questioning and denaturalizing of the concepts themselves. On this occasion I will do so only with democracy, subjectivity and cosmopolitanism, since in other spaces (Buenfil 1983 and 2011a) I have undertaken an exercise on the denaturalizing of education, and several other authors have also decentered it from the school (Ruiz, 2000; Padierna 2009, among others).

Considering the world context in which the subjectivities are formed, I will question globalization and cosmopolitanism. The complexity of the process of internationalization has been simplified through the monocausal version of the imposition of (economic) neoliberalism, so a review of the concept is relevant. The cosmopolitan ideal has been traced back to Diogenes (400 BC), who even then aspired to transcend origins and local associations in favor of becoming a citizen of the world (Nussbaum, 1997). In 1775, in the third article of his Perpetual Peace, Kant said that the right to world citizenship should be limited to the conditions of a universal hospitality. Distant regions could very well enter into peaceful relationships which, by becoming public and legal, could lead mankind to the 
establishment of a cosmopolitan constitution. Cosmopolitanism refers thus, in very general terms, to the right of every individual to not be denied the right to cross borders, as long as they come in peace. This right to hospitality is what constitutes the possibility of being a citizen of the world. Between this idyllic and conciliatory image and the contradictory and often oppressive images that emerge in relations between nations, we see a problem that demands analysis or at least an exercise in contextualization.

The argument that I propose to present for discussion is that if we know the contextual nature of any political value, such as democracy and cosmopolitanism, it is crucial to go beyond adherence or rejection in general terms, and involve oneself in what they mean in each case, so as to take committed action socially, politically and ethically in the formation of subjectivities.

The position of this presentation is postfoundational (Marchart, 2009). It revisits the critique of the subject as the source and origin of meaning (Nietzsche, Foucault, Lacan, Laclau, among others); it adheres to the notion of meaning as use of an expression within a language game (Wittgenstein, 1953); it subscribes to the paradoxical interpretation of democracy (Mouffe, 2003) and the pluralistic cosmopolitical point of view as opposed to conciliatory cosmopolitanism.

I organize this document in four sections, each one of which questions a topic: subjectivity, democracy and cosmopolitanism, and the fourth offers some theses for discussion.

\section{Subjectivity, Identification and Formation}

Although interest in identity, subjectivity, agency, identification, subjectivation and other forms of situating the actions of persons and groups has been taken up by philosophy, sociology, psychology, anthropology, pedagogy, law, and other areas of knowledge, once the imbrication of education in the formation of subjectivities is recognized - that it involves processes of identification - (regardless of whether schooling is alluded to or not), interest is renewed and intensified. In this paper I will only briefly question subjectivation from two points of view: a postfoundational critique, and the decentering of schooling with regard to formation.

Postfoundational questioning(Note 2) does not reject, but rather deconstructs and deontologizes the (supposed) ultimate, definitive and prediscursive foundations, that is, it exhibits its contingent makeup resulting from political relationships. On this level, the questioning of subjectivity has a long history, so I will only mention certain key moments: German romanticism and its emphasis on the constitutive dimension of language, the critique of rationalism and the unconscious dimension of psychoanalysis; the critiques of Heidegger and Nietzsche,

"...This critique has essentially borne upon three conceptual targets: the view of the subject as an agent both rational and transparent to itself; the supposed unity and homogeneity of the ensemble of its positions; and the conception of the subject origin and basis of social relations (Laclau and Mouffe, 1985: 115).

Other questions have derived from these, generating positions on specific aspects that are shared or differ, but that converge on one basic idea: to deontologize subjectivity: Foucault, Hall, Laclau and Mouffe, Scott and Butler, Zizek, Bhabha, among others, have advanced widely known objections, suspicions, revisions and reassessments of the notion of identity from the point of view of anthropology, cultural studies, gender studies, and other areas of knowledge, highlighting processes of identification.

From the angle that emphasizes the formation of subjectivity as a process that occurs inside and outside the school, the way has been paved since the middle of the $20^{\text {th }}$ century not only by classic educators and intellectuals, such as Dewey (1916/1978), Gramsci (1926/1973, 1977), Ponce ( 1934/1981) and later Trilla (1996) in Europe, but also by more contemporary ones, such as Lave and Wagner (1991) in the United States, Freire (1977), and Puiggrós \& Gagliano (2004) in Latin America, and in Mexico, since the 1970s, under the name "informal or incidental education," the work of the Center of Educational Studies (CEE for its initials in Spanish), later Buenfil (1983) and currently those of Ruiz (2000) and Padierna (2009). Throughout history, education in its diverse forms has alluded to forming subjects, the social identities of each era; and it has done so, according to historians, by displaying numerous experiences, both teaching and learning, inside and outside the school. For example:

- diverse spaces or agencies (the family, religious groups, sports organizations, unions and political parties, social movements, schooling and work institutions, amongst others);

- different purposes (training for survival, forming leaders, forming elites, training workers, forming citizens, training athletes, and so on), 
- many in charge people involved (their design in the hands of families, unions, private individuals, designed as institutional policies, as public policies, amongst the most frequent);

- varied cognitive forms (association, memorization, repetition, positive and negative reinforcers, imitation, imagination, experimentation, amongst many others),

- multiple contents (religious, academic, work, social, political, everyday culture, survival, artistic, emotional, communicational, etcetera), and

- different mechanisms and strategies (accompaniment, individual or family mentoring, artisanal learning, tutorship, peer groups, schools of different levels, amongst others).

It is worth remembering that education, as identitary formation, can be favored by teaching, by ever better teaching strategies, environments and designs, but the only way to verify that education has taken place is when the subject somehow shows that they have internalized contents, values, skills, attitudes, and so on (beyond the fact that they are acceptable or not). That is, one knows that education occurred through the learning that takes place through these cognitive forms, contents, mechanisms, strategies, goals and spaces or agencies. Consequently, without failing to recognize the efforts of the school system and other agencies to teach, it is worthwhile to also examine the learnings that take place without having been designed, promoted, expected or desired to this ends, and, as we have insisted, still shape subjectivities. I also do not want to fail to emphasize that internalization involves appropriation, resignification and is not, in any way, isomorphic with what was "taught." Finally, it is worth reiterating that besides the resources that, deliberately and de facto, have promoted subject formation, de facto educational actions also occur in experiences that have been designed specifically for other ends, but allow for valuable (or not) learnings; these unforeseen learnings also intervene in processes of identification, that is, in identitary formation, and not recognizing them does not eliminate their effects in subjective construction, but rather prevents seeing their political, civic, professional, moral, labor, etc. potential.

\section{Discussing Democracy}

Democracy as a value has undoubtedly been cherished by the Mexican political imaginary from Independence to the present time. However, what has been meant by this term in every era, political program and even government bloc obviously changes (Buenfil, 2011b). In different discursive areas, the signifier(Note 3) democracy: a) is present in diverse institutional instances, but with different ideological and enunciative orientation; $b$ ) its signifieds are different and sometimes contradictory depending on who, where and with what purpose it is enunciated (international agencies, Mexican government officials, opposition groups [party, union, working class], etc.; c) is an object of conflict since different agents vie for and would like to fix its meaning. The foregoing characteristics show that despite the differences and, eventually, the antagonisms with regard to their meanings, these signifiers have in common that they are structured as a principle of salvation and a horizon of fulfillment for the community.

This semantic and political variation of meaning poses considerations of a theoretical character that allow us to go beyond the perceptible phenomenon and understand and test arguments about how and why such resignifications are produced; to ask ourselves how we have come to think democracy as we think it today; what political questions and ideas were the condition for the emergence of democracy as a value. With the help of Nietzsche and Foucault (1992) it would be worthwhile to retrace the steps of Western political philosophers to find a "low and minor" place of origin, or a "corrupt form of government," as Aristotle supposedly stated (Bobbio and Mateucci, 1981: 494 and ff). And it would be necessary to walk again along the paths taken by different traditions of thought in order to recognize debates and controversies among varied, different and, eventually, conflicting conceptions of democracy: liberals, rationalists, socialists, communitarian, proceduralists, critical, post-Marxist, and many more.

The enormous semantic proliferation that exists makes it advisable to establish certain central themes around which democracy may be questioned; in this presentation only two will be discussed: the tension between universalism and particularism; and political contextualism. Numerous philosophical arguments have been advanced regarding the futility of continuing to search for the reason from which essence is derived (in the Aristotelian sense: universal, necessary a priori), when we are witnesses to the extensive proliferation of meanings with which the signifier is used, posing the inexistence or nonsense of the often mentioned "essence of democracy." The particularism of the Western notion of democracy has been established as a universality that supposedly functions for the whole planet; however, there are numerous equivalent experiences, culturally organized by other terms and around other values, which make this particularity apparent and situate it where it belongs (Pannikar, 1982).

The signifier democracy refers at the same time to what "we" are or want to be and to what "the enemy" is not. 
Hence, its ambiguity is not circumstantial, but rather constitutive. The polysemous and ambiguous signifier is, in addition, contingently articulated, since on the one hand, the ties between democracy and freedom can have different emphases, meanings and effects in each context, and on the other hand, the principles of one can put the principles of the other at risk: the principle of equality and justice is strained by the liberal emphasis on respect for "human rights," since there is no guarantee that a decision taken through democratic procedures will not challenge certain existing rights (Mouffe, 2010). The impossibility of resolving these tense relationships, more than being seen as demotivating and pessimistic, makes it possible to recognize the contextual dimension of decisions(Note 4) and responsibility.

The political and ethical dimensions (hegemony and responsibility) in the decision to give democracy a partial and temporary meaning are not apparent in a rationale that does not recognize the contingent character of this articulation. The currents of thought that suggest that the meaning of democracy is fixed and a result of a metaphysical "human essence" or of religion; or, in the version of the Enlightenment, derived from reason, economy or science, see political action as administrative instrumentality, as an operative means to put a supposedly "true" meaning of democracy into practice.

In contrast, what I maintain in this document is the political character of the moment itself when a situated community decides a meaning that it is willing to affirm and support, what it puts at risk when deciding on a possible alternative and what it is willing to exclude from such a concept of democracy in a particular context (time and space). Recognizing that the moment of decision is a political one means being willing to account for how and why; and on this level, it refers to the dimension of responsibility.

As Mouffe (2010) points out, rationalist points of view prevent us from recognizing the ineradicable tension; they try to resolve it and to eliminate it, and for this reason base themselves on the illusion of a final "rational consensus." To assume the paradoxical nature of liberal democracy requires different intellectual tools than those of the rationalists, and which allow us to recognize that there is no fixed social meaning possible (i.e., objectivity, essence) that is not based on an exclusion at its origin. What is excluded is, obviously, also the object of negotiation and decision. As I pointed out previously, the subject emerges when they make a decision in a situation of dislocation (for example, regarding the idea of democracy itself) and, in my view, this emergence refers precisely to the educational act, to the experience of subjective formation dealt with in the first section.

\section{Cosmopolitanism, Globalization and Formation}

To rethink democracy in a global context, like the current one, demands recognizing global complexity, which has cosmopolitanism as one of its ideals. In the discussions of these topics, certain notions have already been sedimented that I consider important to examine. The complexity of globalization, as a process of cultural, political, communicational, etc. internationalization, can hardly be grasped by the ingenuous, trite and reductionist formula of the uniform imposition of a neoliberal economy on the planet. Its spheres as ontic phenomena, and as objects of study, its historicity, its religious, cultural, gastronomic, educational, communicational and technological, military, political dimensions, and all the rest, lose visibility by being subordinated to economic monocausality, and its social effects are avoided (instead of being confronted).

Considering the vast literature on the subject, I will only mention that the position I assume does not associate globalization exclusively with a necessary and universal tendency of history (Braudel 1991, Wallerstein 1989), nor with an inevitable cultural, economic, ethical or political imperialization (i.e. the domination of one sole, uniform vision throughout the planet, even if it were not capitalist-(Harvey, 1989, Chomsky \& Dieterich, 1995; Archer, 1991), nor the economic, military, political and cultural exclusion of Asia, Africa and Latin America (Dussel, 1997: 98).

On the contrary, revisiting certain arguments made by Giddens (1990), Robertson (1990), Perlmutter ( 1991) and by Kawame and Gates (1997), I sustain that globalization can also be understood as interconnection, interpenetration of economic tendencies, the contact of cultural diversity, the intertwining of many traditions and the interdependence of political tendencies. This implies recognizing the contemporary existential situation as a multidirectional conditioning and an unsolvable tension of the universal and the particular, the homogeneous and the heterogeneous, fragmentation and integration, centralization and decentralization.

It involves, in fact, the production of hybrid and syncretic cultural, educational and economic programs, and the assumption that there will be no shortage of battles lead by fundamentalists under the pretext of "preserving pure and uncontaminated identities," (i.e., mythical identities). This shows that the interconnection, the contact and the intertwining of the diverse do not occur without consensus and conflict, since our planet displays unequal development in geopolitical spheres and areas. Globalization can be understood as a projection of a certain 
commensurability between the heterogeneous, i.e., contact between the different,(Note 5) without forgetting that tension, clash, friction and conflict, as well as the articulations and agreements, are part of this process and should not be avoided nor veiled behind the certainties of the Enlightenment and faith in undistorted communication. More than a pessimistic vision, this involves a point of view of ethical and political responsibility. The foregoing presupposes a painful, and sometimes even overwhelming, assumption: there is no undistorted communication, no transparent society nor a final resolution of antagonisms; in short, there is no final healing of the social. Thus, once the necessary historical tendencies and quasi transcendental reason are conceptually rejected, the sphere of decision is evidenced, foundational prescriptivism loses support and it becomes evident that it is one who assumes (or not) responsibility for his or her own decisions in context.

These propositions would not associate globalization with a universal, totalizing and necessary trend of history, neither with an inevitable economic, political, ethical or cultural imperialization -i.e. the dominance of one sole and uniform point of view throughout the planet- (even if it were not capitalist).

Contact between differences may lead the planet not toward homogenization or fragmentation, not toward an "either/or" situation, but rather toward points of view that are "both" universalist "as well as" particularist, mixed together and under tension (e.g. coexistence and the interweaving of the points of view of the conqueror and the conquered). For example, with regard to cultural studies the proposal has been the following:

We all participate, although from different positions, in a global system of culture... ever less dominated by the West, less Eurocentric... And so there have to be more and more people in the West, like us, aware both of their ignorance of many traditions of others as well as their eagerness to know more (Kawame \& Gates 1997: xi).

Globalization is understood not as Westernizing, but rather as the transformation of daily life itself (medicine, cooking, art, religion) in Western societies, thus producing syncretic formations. It articulates pluralism in a culturally fragmented post-modern society; it is the first global civilization (cfr. Perlmutter 1991:911).

Others emphasize Western imperialism in a global system of media that produces universalization as well as particularization. (cfr. Robertson 1990:22). The combination of economic, military and political paths has produced this global condition. Capitalism, the interstate system, militarism and industrialism are creating this contingent, discontinuous and unequal development (cfr. Giddens 1990:175).

In this spectrum of viewpoints on globalization, I will sustain here the position that I have assumed in other venues (2000 a and b, and 2009): interdependence, interpenetration, hybridism, economic, cultural, political, demographic, etc. tensions between trends (fragmentation-unification; heterogeneity-homogenization), the analysis of which cannot be reduced completely to an economistic explanation.

With respect to cosmopolitanism, I pointed out in the beginning that Diogenes of Sinope, a member of the Greek tradition of the Cynics (400 BC), already aspired to transcend local loyalties in favor of becoming a citizen of the world. Nevertheless, Kantian thought is perhaps one of the first spaces where we find a systematic reflection regarding cosmopolitanism. Foucault (1961) and Rabinow (1988) focus two approaches to the problem. One in the precritical period of Kantian thought, in which an imperative position (legal), where Reason would be capable of channeling cultural differences, is characterized as cosmopolitan; and another that is pragmatic, characterized as cosmopolitical, where culture, situated in history, would produce articulations of the universal and the particular, constituting the limits of our experience.

Jacques Derrida (1991), for his part, finds a certain tension in Kantian thought, since on the one hand hospitality should be a right for the person who arrives, but there should always be conditions for the exercise of that right.

Mouffe (2010 and 2011) also critiques cosmopolitanism articulated toward universal approaches, and believes that these contribute to the clash of civilizations, since by trying to impose the Western conception of democracy, considered as the only legitimate one, on societies that reject it, they necessarily end up presenting those who do not accept the concept as "enemies of civilization;" this negates their right to maintain their cultures, and creates conditions for an antagonistic confrontation between different civilizations. Only by recognizing the legitimacy of a plurality of just social forms, and the fact that liberal democracy is only one form of democracy among others, that conditions can be created for an "agonistic" coexistence between different regional poles with their specific institutions. This multipolar order, Mouffe maintains, certainly does not eliminate conflict; but it is less probable that this conflict will adopt antagonistic forms than in a world that leaves no space for pluralism. In this sense, we should not ignore numerous works that show varied and equivalent strategies of thinking and organizing other "democratic" forms, other "modernities" and "Enlightenments," among the most well-known (Chakrabarty, 2000; Hunter, 1991; 
Feldman, 2008).

The consequences of cosmopolitanism in the last two decades of the $20^{\text {th }}$ century and what has transpired in the $21^{\text {st }}$ have paved the way for new debates, although some naturalized characteristic ideas remain regarding this question. The coexistence of different religions, the strong movement toward national borders, the possibility of constructing a universal moral community, the world citizen and universal rights are some examples.

Another viewpoint is that proposed by Popkewitz (2007), who observes cosmopolitanism critically from the position of systems of reason that regulate education, functioning as a gesture to unify the whole through universal values of reason and awareness of modernity. Popkewitz highlights the aporia between the "sacred hope of the future," loaded with Western values of emancipation (including individual freedom and forms of social administration) and the fears derived from the comparison conducted to differentiate populations in poles of civilized and savage, and thus justify the parameters of systems of inclusion/exclusion.

The dual quality of cosmopolitan hopes and fears has imbued educational reforms in the school throughout life, teaching through problem-solving, the Learning Society, Popkewitz (2007) points out, noting the tension between universalism and particularism in the unifying efforts of these international mandates inscribed in educational policies. The hope of the cosmopolitan child rushes along with the fear of the dangers and the menacing population.

It is within these coordinates of intellection that our global and cosmopolitan existential conditions are interpreted critically and acritically, and where subjectivities are formed. Hence the interest in distinguishing the unidirectional, homogenizing, universalist version, whether triumphalist or catastrophic, regulated by Reason; in the face of multidireccional, aporetic, pluralist and cosmopolitical versions, where the force of reason will always be under strain with other driving, political, moral, judicial forces and the rest.(Note 6)

\section{Points for Debate}

I have questioned the sedimented notions of subjectivity, its formation and how this constitutes educational action understood as learning, that is, as the appropriation and resignification of identitary offerings(Note 7) (i.e., interpellation) that are culturally available. I have questioned the possibility of providing the value of democracy with an ultimate, fixed meaning, arguing its polysemous character, its ambiguity and contingency. I have questioned the notions of globalization and cosmopolitanism so often repeated in contemporary educational imaginaries, showing their irreducible complexity into economistic explanations, and the tensions between notions of cosmopolitanism that tend toward the search for exclusion of conflict, and those that recognize the agonistic possibility of conflictive plural negotiations. I thus tried to offer other tools of intellection to interpret our contemporary global conditions toward the formation of democratic subjectivities and of a pluralistic cosmopolitics, keeping always in mind its contextual nature.

With these tools it is possible to examine notions that prevail in the educational field and that, with the best of intentions, take back from the Enlightenment and rationalism the supposedly fixed foundations of democracy and cosmopolitanism, and then make them pedagogically manageable (i.e., operationalize them) so that "students" (of any age) will "learn them." Ethically, politically and educationally, I do not share decontextualized prescriptivism nor that type of position, since if we believe that God or Nature have made the world "as it is," or, in its enlightened version, that Science and Reason are the ultimate foundation of truth and rightness (frequent foundationalist trappings in the history of Western thought), it is probable that we would consider our fate as something inevitable. But if we recognize that being in the world that we inhabit is the result of the contingent discourses and appropriations that constitute it, we will assume a different outlook with regard to "destiny" and will have a greater possibility of making decisions in this regard and of being responsible for the results. The perception of the contingent character of universal — or rather, universalized — values allows us to visualize their precariousness and take a position with regard to it (Laclau, 1996, 212-213).

I trust that we are capable of putting our intellectual apparatus to work, our ethical reflection and our political and cultural sensibility, to construct the possible meanings of democracy, globalization, cosmopolitanism that we want and that we do not want; what we are willing to defend in our micro-physical, local, state, national, regional, international contexts, that is, where we are situated, from a broad educational perspective: as formation of subjectivities. It is not enough to recognize political and civic differences between cultures, continents and nations. Aside from questioning, what is needed is the construction of contextualized outlooks, a construction that, fortunately, will never be able to be considered finished once and for all, but rather will involve endless negotiations according to new contexts and social demands, will entail consensus and conflict between plural positions, and will 
inevitably bring about the inclusion of some values and the exclusion of others.

\section{Acknowledgements}

I am grateful to MSc Laura Echavarría for her work on the bibliography and to Drs. Juliana Enrico and Ernesto Treviño for their critical reading of the draft. The errors that remain are my responsibility.

\section{References}

Archer, M. S. (1991). Sociology for one world: unity and diversity. International Sociology, 6(2), 131-47. http://dx.doi.org/10.1177/026858091006002001

Bobbio, N. y N. Matteucci (1982). Diccionario de política. México, D. F.: Siglo XXI.

Braudel, F. (1991) .Escritos sobre la historia. México: Fondo de Cultura Económica.

Buenfil Burgos R. N. (2011a). Territorialidad global, espacios educativos y cosmopolitismo. En: V Encuentro de Análisis Político de Discurso. Políticas Educativas y Formación de Sujetos. México: Facultad de Filosofía y Letras-UNAM, CD.

Buenfil Burgos, R. N. (2011b). Discutir la democracia en el campo educativo. Revista Interamericana de Educación para la Democracia (en prensa)

Buenfil Burgos, R.N. (2009). Politics, global territories and educational spaces. In Globalization and the Study of Education. The 108th Yearbook of the National Society for the Study of Education V. II. (pp 67-88), Massachusetts: Wiley-Blackwell. http://dx.doi.org/10.1111/j.1744-7984.2009.01162.x

Buenfil, R. N. (1983). El debate sobre el sujeto en el discurso marxista: Notas críticas sobre el reduccionismo de clase y educación. México: DIE- Cinvestav.

Buenfil, R. N. (2000a). Globalization, education and discourse political analysis. Ambiguity and accountability in research. International Journal of Qualitative Studies in Education, 13(1), 1-2. http://dx.doi.org/10.1080/095183900235708

Buenfil, R. N. (2000b). Globalization and Educational Policies in Mexico, 1988-1994: A Meeting of the Universal and the Particular. In Stromquist, N. y K. Monkman (Eds.) Globalization and Education. Integration and Contestation across Cultures, (pp. 275-297). New York, Toronto, and Oxford: Rowman \& Littlefield.

Chakrabarty, D. (2000). Provincializing: Postcolonial Thought and Historical Difference. New Jersey: Princeton University Press.

Chomsky, N., \& H. Dieterich. (1995). La sociedad global. México: Joaquín Mortiz .

De Saussure, F. (1959). Curso de Lingüistica General . México DF: Nuevo Mar.

Derrida, J. (1982). Margins of Philosophy. Brighton, Harvester Press.

Derrida, J. (1991). El derecho a la filosofia desde el punto de vista cosmopolítico. Conferencia auspiciada por UNESCO.

Dewey, J. (1916/1978). Democracia y educación. Buenos Aires: Losada.

Dussel, E. (1997). Modernidad, globalización y exclusión en Dieterich, H. Globalización, Exclusión y Democracia en América Latina. México: Ed. Joaquín Mortiz.

Feldman, N. (2008). The Fall and Rise of the Islamic State. New Jersey: Princeton University Press.

Foucault, M. (1961). Una lectura de Kant. México: Siglo XXI.

Foucault, M. (1992). Nietzsche, la Genealogía, la Historia En: Microfísica del poder. Madrid: La Piqueta.

Freire, P. (1977). Pedagogía del oprimido. México: Siglo XXI.

Giddens, A. (1990). The Consequences of Modernity. Cambridge: Polity Press.

Gramsci, A. (1973). La alternativa pedagógica. Barcelona: Nova Terra.

Gramsci, A. (1977). Cuadernos de la cárcel. México: Ed. Era.

Harvey, D. (1989). The Condition of Postmodernity. London: Basil Blackwell. 
Hunter, J. (1991). Culture Wars. The struggle to define America. Nueva York: Basic Books.

Kant, I. (1775/2001). Sobre la Paz Perpetua. Madrid: Alianza Editorial.

Kawame A. A., \& H. L. Gates (1997). The dictionary of global. New York: Alfred A. Knopf.

Laclau, E. (1990). Nuevas Reflexiones sobre las revoluciones de nuestro tiempo. Buenos Aires: Nueva Visión.

Laclau, E. (1996). Emancipación y diferencia. Buenos Aires: Ariel.

Laclau, E. y C. Mouffe. (1985). Hegemony and Socialist Strategy. London: Verso

Lave, J., \& Wenger, E. (1991). Situated Learning: Legitimate Peripheral Participation. New York: Cambridge University Press. http://dx.doi.org/10.1017/CBO9780511815355

Lyotard, J. F. (1988). La diferencia. Barcelona: Gedisa.

Marchart, O. (2009). El pensamiento político postfundacional en Nancy, Lefort, Badiou y Laclau. Buenos Aires: Fondo de Cultura Económica.

Mouffe, C. (2003). La paradoja democratic. Barcelona: Gedisa.

Mouffe, C. (2010). Política agonística en un mundo multipolar. Barcelona: Fundación CIDOB.

Mouffe, C. (2011). Pueden los derechos humanos acomodarse al pluralismo? en Buenfil, R. N. y Z. Navarrete (2011) Discursos educativos, identidades y formación profesional. Producciones desde el Análisis político de discurso, México: Plaza y Valdés-PAPDI.

Nietzsche, F. W. (1887/1972). La genealogía de la moral. Madrid: Alianza Editorial.

Nussbaum, M. (1997). Cultivating Humanity: A Classical Defense of Reform in Liberal Education. Cambridge: Harvard University Press.

Padierna, M. P. (2009). Construcción de foros para la práctica ciudadana: mujeres zapatistas en Soriano, R. y Ávalos. D. (coords.) Análisis Político de Discurso. Dispositivos intelectuales en la investigación social, (pp. 65-73), México, D. F.: Juan Pablos-PAPDI.

Panikkar, R. (1982). Is the Notion of Human Rights a Western Concept? Diogenes, 120, 75-102. http://dx.doi.org/10.1177/039219218203012005

Perlmutter, H. V. (1991). On the rocky road to the first global civilization. Human Relations, 44(9), 897-1010. http://dx.doi.org/10.1177/001872679104400901

Ponce, A. (1934/1981). Educación y lucha de clases. México: Editores Mexicanos Unidos.

Popkewitz, T. (2007). La razón de la esperanza cosmopolita como miedo a la diferencia. En Padierna, P y R. Mariñez Educación y comunicación. Tejidos desde el Análisis político de discurso (pp. 433-466) México: Juan Pablos-PAPDI.

Puiggrós, A. y Gagliano, R. (2004). La fábrica del conocimiento. Rosario: Homo Sapiens Ediciones.

Rabinow, P. (1988). Beyond Ethnography: Anthropology as Nominalism. Cultural Anthropology, 3(4), 355-364. http://dx.doi.org/10.1525/can.1988.3.4.02a00010

Robertson, R. (1990). Mapping the global condition. In Featherstone, M. (ed.) (1990) Global Culture. London: Sage.

Ruiz, M. (2000). Imbricación de lo político y lo pedagógico en los procesos de educación de adultos: dos estudios en caso. México: DIE-Cinvestav.

Trilla, J. (1996). La educación fuera de la escuela. Ámbitos no formales y educación social. México: Ariel.

Wallerstein, I. (1989). El capitalismo tardío. México: Siglo XXI.

Wittgenstein, L. (1953). Investigaciones Filosóficas. México: Alianza e IIF-UNAM.

\section{Notes}

Note 1. My reluctance to offer a prescription, as will become evident later in this paper, is due to my maintaining the contextual character of signification, therefore, of any political, moral, epistemic or esthetic value. In other words, the epistemic critique of universalism surrounds and pervades my own political positions in this paper.

Note 2. Postfoundationalism, in my opinion, has family similarities with (although it is not the same as) many of the 
"post" critiques made in the second half of the 20th century: post-structuralism, post-analytic, post-phenomenology, post-Marxism, and even post-modernity (which is not common in any way, nor much less does it promote the infamous "anything goes," as Marchart declared, 2009: 14).

Note 3. By signifier I refer to a component of the sign, inseparable from the signified, but whose ties are contingent. It is the acoustic image, the psychic trace (as Saussure, 1959, would say). See Derrida's discussion with regard to différance and the possibility of reiteration (1982, $11 \mathrm{ff}$ and 315).

Note 4. It is worth clarifying, if only schematically, that decision does not refer to a rational calculation, but rather to the critical moment (which is simultaneously rational, passionate, compulsive, etc.) when the limits are defined between what is included and what is excluded in a project, program, concept or value. It refers to a constitutive political relationship of all identities (i.e., to the political ontology maintained by Laclau in 1990), and which involves the formation of subjective identities, that is, the educational dimension.

Note 5. The metaphor of Lyotard's (1988) archipelago allows us to visualize this possibility, since it recognizes the separation of the islands, but also that they are communicated by the sea.

Note 6. The " $\mathrm{R}$ " and "r" in the word "reason" is deliberate: with a capital letter to refer to the Kantian idea of reason and with a small letter to refer to the notion that prevails in each context.

Note 7. By "identitary offering" I am not referring to the language of "pedagogical market" (with "clients" and all the rest), as some analysts would observe the educational process. I refer to the availability of existing subject positions in a context, in the social spaces, with the contents, strategies, etc. already mentioned in the first section of this paper. 